\title{
Late Quaternary morphodynamics in the Quebrada de Purmamarca, NW Argentina
}

\author{
Jan-Hendrik May, Ramiro Daniel Soler
}

\begin{abstract}
:
This study aims to document the geomorphic, sedimentary and paleopedogenic archives in the Quebrada de Purmamarca. The paleoenvironmental interpretation of these archives and the reconstruction of landscape evolution are mainly based on field observations and geomorphological mapping (MAY 2008). A series of aggradational terraces mostly consisting of coarse debrisflow deposits are the main focus of this investigation. While the associated cut-and-fill processes are probably the result of an interplay between climatic and tectonic controls, the deposition of the youngest terrace level (> 150 m thickness) may likely be attributed to a drop of the periglacial belt of more than 1000 meters below its modern elevation. For the time after terrace accumulation has ceased, the interpretation of alluvial fans, aeolian sand and a well-developed paleosol points to Late Quaternary humidity changes as an important control on landscape evolution. The major phase of downcutting and incision significantly postdates the end of terrace deposition and may have been triggered by markedly increased amounts of monsoonal precipitation. Finally, minor humidity changes of possible Holocene age are indicated by paleopedogenic and geomorphic observations on terrace surfaces and along valley slopes.
\end{abstract}

\section{[Spätquartäre Morphodynamik in der Quebrada de Purmamarca, NW Argentina]}

Kurzfassung

Ziel dieser Arbeit ist die Dokumentation geomorphologischer, sedimentärer und paläopedologischer Archive in der Quebrada de Purmamarca. Die Interpretation dieser Archive in Bezug auf die Paläoumweltbedingungen basiert hauptsächlich auf Feldforschungen und geomorphologischer Kartierung (MAY 2008). Einen Schwerpunkt dieser Studie bildet eine aus grobem Material aufgeschüttete Terrassenfolge. Während die Erosions- und Akkumulationsprozesse vermutlich auf das Zusammenspiel klimatischer und tektonischer Prozesse zurückzuführen sind, steht die Ablagerung der jüngsten ca. $150 \mathrm{~m}$ mächtigen Terrassenfläche wohl in Zusammenhang mit dem Absinken des periglazialen Einflussbereiches um mehr als $1000 \mathrm{~m}$ unter die heutige Höhenlage. Nach dem Ende der Terrassenschüttung, bieten vor allem Schwemmkegel, äolische Sande und gut entwickelte Paläoböden wertvolle Hinweise auf die durch Feuchtigkeitsveränderungen gesteuerte spätglaziale Landschaftsentwicklung. Die Hauptphase der Einschneidung datiert um einiges nach dem Ende der Terrassenaufschüttung und wurde vermutlich durch eine Zunahme der monsunalen Niederschläge gesteuert. Abschließend konnten die Auswirkungen kleinerer, vermutlich holozäner Schwankungen der Feuchtigkeitsverhältnisse über paläopedologische und geomorphologische Beobachtungen auf der Terrassenoberfläche und den Hängen beschrieben werden.

Keywords: $\quad$ Andes, landscape evolution, Late Quaternary, terraces, paleoenvironments

Addresses of authors: Jan-Hendrik May*, School of Earth and Environmental Sciences, University of Wollongong, 2522 Wollongong NSW, Australia; E-Mail: hmay@uow.edu.au; Institute of Geography, University of Bern, Hallerstraße 12, CH-3012 Bern, Switzerland. E-Mail: may@giub.unibe.ch / Ramiro Daniel Soler, CNEA (Comision Nacional Energía Atómica), Avenida Bolivia 1235, 4400 Salta, Argentina. *corresponding author

\section{Introduction}

The Andean ranges of NW Argentina are situated between the high-altitude plateau of the Puna and the vast Chaco lowlands, and are characterized by steep climatic and topographic gradients. This makes them a highly dynamic area from geological, environmental and geomorphological perspectives. The thick and complex series of Tertiary and Quaternary depositional terraces and alluvial fans along the intramontane valleys of the Eastern Cordillera have drawn the attention of early geologists (KEIDEL 1913; KüHN 1924; De FERrARIS 1940). Since then much research has been directed towards a more detailed comprehension of landscape evolution on these Cenozoic timescales, particularly with regard to the repeated and oscillatory filling and excavation of the Andean valley systems in NW Argentina by a complex interplay of climate and tectonics (KLEINERT \& STRECKer 2001; Hilley \& STRECKer 2005; Alonso ET Al. 2006; STRECKer ET AL. 2007). In this context, the interac- tions and relative importance of the climatic verse tectonic controls are a matter of ongoing debate and should vary on different timescales (Hilley \& STRECKER 2005). Consequently, increasing effort has recently been concentrated on the establishment of an absolute chronological framework for the Quaternary alluvial fans and valley fill deposits along intramontane valley systems of the Quebrada de Toro and Quebrada de Humahuaca (RoBINSON ET AL. 2005; SANCHO ET AL. 2008; SPENCER \& RoBinson 2008).

Given the crucial role of climate in landscape evolution, a number of studies have been concerned with the reconstruction of paleoclimate and paleoenvironments from different archives in the Andes of NW Argentina over various Quaternary timescales. Cyclic changes in moisture availability in NW Argentina throughout the Quaternary were suggested by the investigation of loess-paleosol-sequences in the Tafi valley (Schellenberger, Heller \& Veit 2003; Kemp et al. 2004; SCHELlenBerger 2006; SCHELlENBERGER \& VEIT 2006). Evidence for periods of increased humidity is provided by 


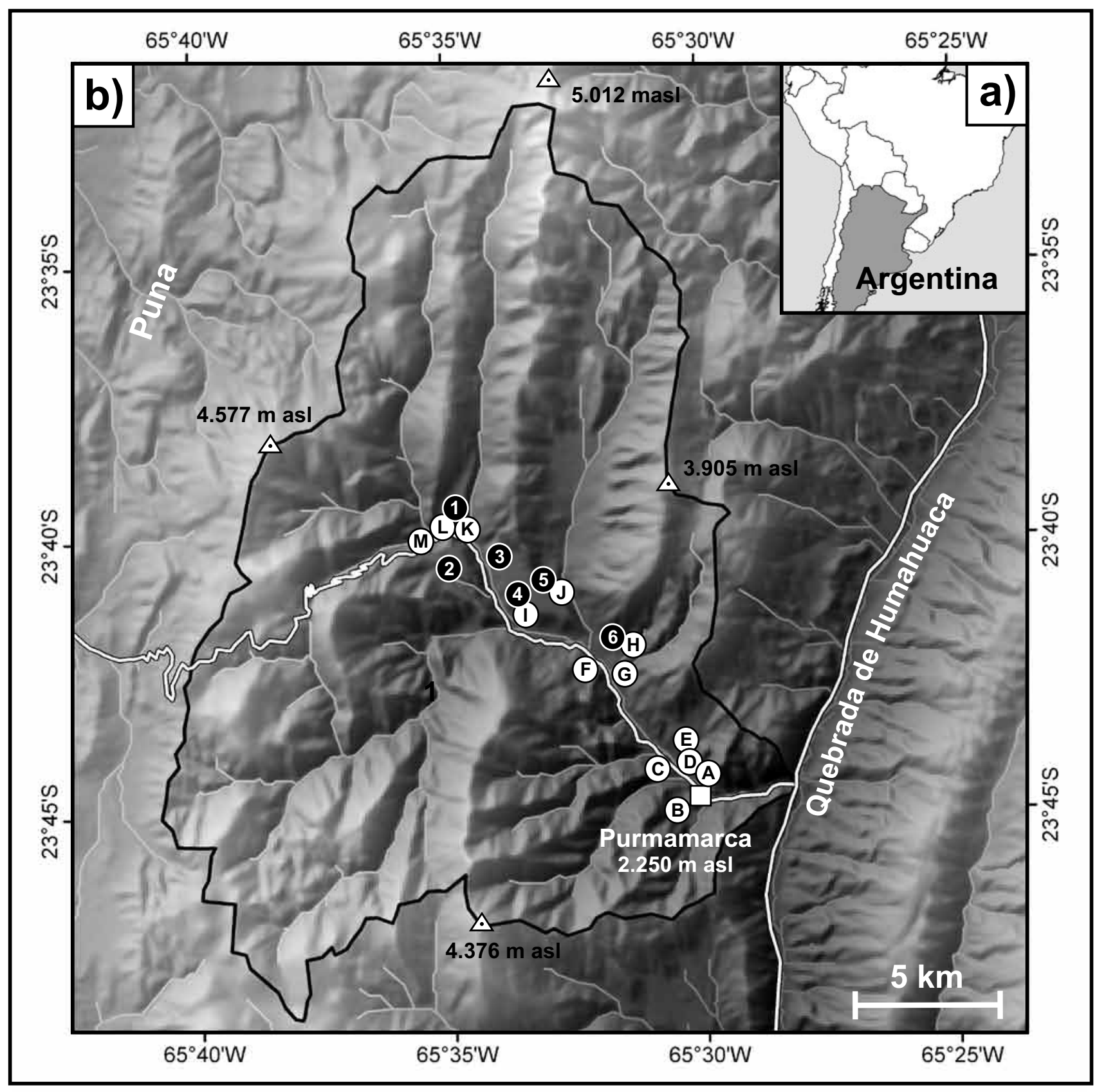

Fig. 1: Overview of the study area. a) Location of the Quebrada de Purmamarca in South America. b) Geographic context and hillshaded topography of the study area (black line denotes catchment divides, grey lines are major streams, white lines are roads) including locations of sedimentary profiles (letters, see Fig. 3) and excavated pits (numbers, see Fig. 4).

Abb. 1: Überblick über das Untersuchungsgebiet. a) Lage der Quebrada de Purmamarca in Südamerika. b) Geographischer Kontext und Topographie des Untersuchungsgebietes (schwarze Linie kennzeichnet die Einzugsgebietgrenze, graue Linie kennzeichnet die Hauptgerinne, weisse Linie kennzeichnet Strassen) einschliesslich der Lage der Sedimentprofile (Buchstaben, siehe Abb. 3) und Bodenprofile (Nummern, siehe Abb. 4).

the coincidence of landslide deposits and lake damming in various intramontane valleys in NW Argentina (TRAUTH ET al. 2000; Bookhagen, Haselton \& Trauth 2001; Trauth ET AL. 2003; Hermanns \& Schellenberger 2008), and may correlate to prominent lake transgression phases on the Bolivian Altiplano during the last glacial cycle (ArGollo o Mourguiart 2000; BAKER et al. 2001; BAKER et al. 2001; FrITZ et al. 2004; Placzek, QuAde \& PATchett 2006). In higher elevations, mapping and modelling efforts on mainly glacial but also periglacial archives have documented evidence for severe temperature reductions in NW Argentina, which triggered the decrease of vegetation belts and snowlines, and multiple glacial advances in the Late Quaternary (
BITZ 1999; ZipPrich ET AL. 2000; AhumadA 2002; HASElton, Hilley \& StRecker 2002; Kull ET AL. 2003; Kull ET Al. 2008). On Holocene timescales, the analysis of sedimentary and archaeological archives along the Quebrada de Humahuaca and in the Eastern Cordillera has produced manifold evidence for variations in precipitation amounts and distribution with a marked dry phase during the Mid-Holocene and the return to modern, semi-arid conditions within the last 2 ka BP (Fernández 1984; Alcalde \& Kulemeyer 1999; Kulemeyer et Al. 1999; MAAS et Al. 1999; Kulemeyer 2005; YACOBACCIO \& MORALES 2005; LUPO ET AL. 2006).

Most of these results are based on the detailed analysis of a single archive or location. Only very few studies have fo- 
cused on a comprehensive documentation and interpretation of the extensive geomorphological records, which are stored in the landscape of the intramontane basins in NW Argentina (Werner 1984; TChilinguirian \& PEREYRA 2001; MAY 2008). Consequently, relatively little is known with regard to the relative importance of paleoclimate and paleoenvironmental changes, and their imprints and controls on landscape evolution and geomorphic processes over different timescales. An improved understanding of landforms and their evolution at and beyond catchment scale is also the base for the assessment and management of modern local geomorphic processes. This is of particular importance in the Quebrada de Purmamarca as a key location for intercontinental transport, tourism and cultural heritage throughout Argentina.

Thus, this study aims to i) document the geomorphic, sedimentary and paleopedogenic archives in the Quebrada de Purmamarca, and ii) discuss their relative timing and paleoenvironmental significance. Thereby, the study establishes a framework of regional landscape evolution and contributes to our understanding of the mechanisms and controls of geological, geomorphic and climatic change over different Late Quaternary timescales in NW Argentina.

\section{Study Area}

The Quebrada de Purmamarca is a $\sim 380 \mathrm{~km}^{2}$ drainage basin in the province of Jujuy, NW Argentina (Fig. 1). It is located in the Eastern Cordillera of the Andes, which forms the transition between the high-altitude plateau of the Puna to the west, and Subandean Ranges and Chaco lowland to the east. Geologically, the Eastern Cordillera is an active foldand thrust belt (MoN \& SALFITy 1995). Topographic ranges are usually associated with high angle thrust faults, which are responsible for the development of asymmetric valleys along the lines of structural weakness (IgARZÁBAL 1991). Several superimposed Paleozoic and Mesozoic tectonic stages are recognized, before major uplift and deformation of the Andean orogeny commenced $\sim 10$ Ma ago, ultimately resulting in the present structural and topographic framework of the Eastern Cordillera (MON \& SALFITY 1995; SALfiTy ET AL. 1996; KenNAN 2000; ReynoldS ET AL. 2000; ReynoldS ET AL. 2001). Significant neotectonic events, which have locally deformed and thrusted Quaternary sediments, did probably not affect NW Argentina synchronously, but generally occurred $>1 \mathrm{Ma}$ ago throughout the Eastern Cordillera (SALFITY ET AL. 1984; STRECKer ET AL. 1989; MARRETt \& STRECKer 2000; Hilley \& STRECKer 2005). As an important factor for local variability of erosional resistance, the main lithologies in the Quebrada de Purmamarca comprise moderately soft quartzitic schists, phyllites and slates of the Precambrian Puncoviscana Formation, the highly resistant quartzitic sandstones and quartzites of the Cambrian Mesón Group, and the easily erodible pelites and greywackes of the Ordovician Santa Victoria Group (RAmos, TuRIC \& ZUZEK 1967; TuRNER 1970; AMENGUAL \& ZANETTINI 1974).

The regional climate of NW Argentina is mainly influenced by tropical humid air masses of Atlantic origin, which are transported into the area by the South American Summer Monsoon, accounting for the large seasonality with most of the total annual precipitation falling in austral summer (BI-
ANCHI $\mho$ Yañez 1992; Garreaud $ひ$ Aceituno 2007). Due to topographic and rain shadow effects, however, precipitation amounts may significantly vary at regional and local scales, and average $96 \mathrm{~mm}$ at the village of Purmamarca (BIANCHI ひ YAÑEZ 1992; ENDLICHER 1995; SOLER 2002). Temperatures in the study area are very variable and particularly at high elevations, the thermal amplitude shows very strong daily variations. Consequently, the annual average height of the $0^{\circ} \mathrm{C}$-isotherm is subject to regional and even local variations and has been estimated between 4500 and $5400 \mathrm{~m}$ asl, while the regional annual temperature gradients in NW Argentina roughly average $0.5-0.6^{\circ} \mathrm{C} / 100 \mathrm{~m}$ (ProhaskA 1976; RuthSATZ 1977; Fox \& STRECKer 1991).

Under these environmental conditions modern pedogenesis is relatively weak, leading to the formation of thin $\mathrm{A}_{\mathrm{h}}$-horizons and carbonate accumulation in the subsoil as the dominant pedogenic processes (WERNER 1971; RUTHSATZ 1977). Most other, more intensively developed soil horizons are probably relics of wetter past climatic conditions (KRISL 1999). The morphodynamic situation in the Quebrada de Purmamarca is dominated by strong badland formation and gullying along and up the valley slopes, having led to floodplain aggradation and intense debris flow dynamics over the last decades (Becker 1966; Aguero 1986; Chayle \& Wayne 1995; Cencetti, Rivelli \& Tacconi 2006). Throughout the entire Quebrada de Humahuaca drainage basin, human impact has likely enhanced the degradation of vegetation cover and slopes since at least two thousand years (GARcía CoDRON ET AL. 1999; LUPO ET AL. 2006).

\section{Methods}

The major part of this study is based on the documentation of geomorphological and sedimentological field work, which was carried out between March and June 2001. Geomorphological field work encompassed the thorough and GPS aided mapping of landforms and processes in all accessible parts of the catchment. In combination with remote sensing data, this information was subsequently compiled and illustrated in a geomorphological map of the Quebrada de Purmamarca (MAY 2008).

Sedimentological description and the classification of the mostly coarse-grained valley fill deposits in the Quebrada de Purmamarca were predominantly based on existing approaches by (NeMEC \& STEEL 1984; Milana 1994; Miall 1996; Nemec \& KazAnci 1999), resulting in the differentiation of six different sedimentary facies (Table 1). Sedimentary profiles of terrace and alluvial fan outcrops were established at 13 different locations along gully walls. Plant remains extracted from one profile were dated by AMS radiocarbon dating at the University of Kiel, Germany (code KIA 17090).

At 12 locations excavated pits and outcrops were documented on top of the terrace and alluvial fan surfaces in order to gain information on soils, paleosols and cover deposits. The field documentation of these pits was based on FAO guidelines (FAO 2006), and the presence of $\mathrm{CaCO}_{3}$ was tested with $10 \% \mathrm{HCl}$. Finally, thin sections from carbonate and sand crusts were taken. Their micromorphological analysis focussed on paleopedological features and the interpretation of genetic processes of soil formation following FITzPATRICK (1993) and Wilson \& NetTLETON (2009). 


\section{Results}

\section{1. Geomorphological context and landforms}

Three contrasting geomorphological zones are generally distinguished throughout the Eastern Cordillera and differ considerably with regard to their relief, i.e. topography and altitude (Fig. 2a). Each zone comprises a typical suite of genetic landforms and geomorphic processes (SEGEMARITGE 1998; TChILINGUirian \& Pereyra 2001; MAY 2008).

i) The highest parts of the study area above $\sim 4400-4500 \mathrm{~m}$ asl are characterized by steep, straight to concave slopes of $25^{\circ}-40^{\circ}$, locally up to $50^{\circ}$ inclination, covered by long tongues of rock debris of different colours and lithologies extending downslope from crests, cliffs and ridges. These observations indicate active and intense production of frost debris and effective downslope transport by shallow solifluction processes, pointing to the presence of permafrost and frequent (daily to seasonal) freeze-thaw cycles. Solifluction lobes were observed in the study area down to $\sim 4000-4100 \mathrm{~m}$ asl, where they are partially stabilized by vegetation. Their lower limit typically represents a transitional belt characterized by the discontinuous and spatially variable occurrence of freeze-thaw related active processes. Thus, over longer timescales, dominant cryogenic or periglacial processes are responsible for the formation of the gentle, rectilinear to convexo-concavo debris-mantled slopes of markedly smooth morphology, which characterize mountain tops and mountain chains in the upper study area and are referred to as 'Glatthang' (glatt = smooth, hang $=$ slope) in the German literature (Fig. 2a; HAGEDORN 1970; Stingl \& GARlefF 1983; Abraham DE VAzQUEZ ET AL. 2000; AhumadA 2002). In the Quebrada de Purmamarca, the lower limit of this type of periglacial slope morphology varies to some extent, e.g. due to dissection by ongoing erosional processes, but reaches well below the limit of active periglacial processes to an elevation of $3300 \mathrm{~m}$ asl (Fig. 2a). As exposed along several roadcuts, the debris covering the slopes above $\sim 3300 \mathrm{~m}$ asl is composed of angular clasts but varies considerably in thickness from few decimeters to $>10 \mathrm{~m}$. The sediments show a clear stratification of relatively fine clasts of the underlying dark grey Precambrian schist at the base, and several subhorizontal layers of coarse, poorly sorted and angular clasts of mainly Cambrian quartzites which are supported by a fine-grained matrix (Fig. 2b).
The exposed internal architecture of slope sediments likely reflects i) the onset of dominant permafrost conditions with intensified mechanical weathering of autochthonous (Precambrian) lithologies, and ii) the successive downslope transport and layered deposition of allochthonous frost debris (of Cambrian lithologies) by solifluction processes, eventually smoothening a pre-existing topography, which had formed during a preceding phase of enhanced fluvial processes. The marked dominance of Cambrian quarzitic lithologies over Precambrian schists and phyllites results from their higher resistivity against cryogenic weathering (e.g. frost cracking) and predisposition for the production of frost debris, also implying their preferential preservation in the sedimentary record. The lowermost evidence for past periglacial processes in the study area are asymmetrically developed slopes, which characterize the drainage channels on top of the higher, older terrace segments and reflect preferential solifluction processes along the north-exposed slopes as the result of past periglacial processes down to $\sim 3100 \mathrm{~m}$ asl (MAY 2002).

ii) The transition between the upper catchment of predominantly periglacial geomorphology and the valleys is characterized by straight to convex slope segments (Fig. 2a). Most of these slopes between $\sim 2600$ and 3800 m asl are strongly dissected by parallel and closely spaced single-branched rills and gullies of variable depth. A knickpoint marks their upslope initiation and actively ongoing headward growth. It coincides with the transition from convex and debris-covered periglacial mountain tops described above to the steeper, straight slope segments where overland flow concentrates. Most of these channels have adjusted to inactive terrace surfaces, and only a few larger channels drain onto the modern floodplain. The onset of slope dissection should therefore postdate terrace deposition and may have commenced synchronously with terrace incision and degradation. The high intensity of slope dissection observed today is possibly amplified by grazing and degradation of vegetation leading to an additional increase in surface runoff, gullying and significant contributions of sediment to the valley floors (AGUERO 1986; CENCETTI, Rivelli \& TACCONI 2006). In addition, several landslides of up to $0.07 \mathrm{~km}^{2}$ were mapped along the lower valley slopes both within the terrace deposits and bedrock (Fig. 2c; MAY 2002). Some of the landslides are partly buried by modern floodplain deposits and must have formed within an oversteepened valley, which was probably created in relation to rapid and profound incision preceding the onset of renewed floodplain aggradation.

Fig. 2: Major landforms, sedimentary and pedogenic features of the Quebrada de Purmamarca (see text for details). a) Altitudinal zonation of periglacial topography (I), slope segments (II) and depositional landforms (III) such as alluvial fan generations A1 and A2, and terrace T3. b) Exposed periglacial slope deposits filling a paleovalley (note person for scale). c) Landslide deposit (circle) and the corresponding scar (line). d) Typical association of badlands, colluvial slopes and A3 alluvial fans along the terrace T3. e) Pinkish terrace sediments of T3 terrace overlain by grey alluvial fan sediments of A1 generation; note the carbonate horizons characterizing the upper most meters. f) Reddish, clay-rich paleosol which has formed in the uppermost T3 sediments and divides terrace from alluvial fan sediments of generation A1. g) Clayey to silty lacustrine rhythmites intercalated within T3 sediments. h) Partly eroded segment of sandy cover deposits on top of terrace T3; note inclination towards the incised stream channel.

Abb. 2: Wesentliche Formen, sedimentäre und pedogene Befunde der Quebrada de Purmamarca (siehe Text für Details). a) Höhenzone periglazialer Topographie (I), Hangsegmente (II) und Ablagerungsformen (III), z.B. Schwemmfächergenerationen A1 und A2, sowie Terrasse T3. b) Aufgeschlossene periglaziale Hangsedimente, die ein Paläotälchen auffüllen (man beachte die Person als Massstab). c) Hangrutsch (Kreis) und die dazugehörige Abrisskante (Linie). d) Typische Vergesellschaftung von Badlands, Hangschuttkegeln und A3 Schwemmfächern entlang der T3 Terrasse. e) Rosafarbene Sedimente der T3 Terrasse, die von grauen Sedimenten der A1 Schwemmfächergeneration überlagert werden; man beachte die Karbonatanreicherungshorizonte, welche die oberen Meter characterisieren. f) Roter, tonangereicherter Paläoboden, der sich in den obersten T3 Sedimenten ausgebildet hat und Terrassensedimente von A1 Schwemmfächersedimenten trennt. g) Tonig-schluffige Rhythmite, die in T3 Sedimente eingelagert sind. h) Teilweise erodiertes Segment eines sandigen Decksedimentes auf der Oberfläche der T3 Terrasse; man beachte die leichte Neigung hin zum eingeschnittenen Gerinne. 

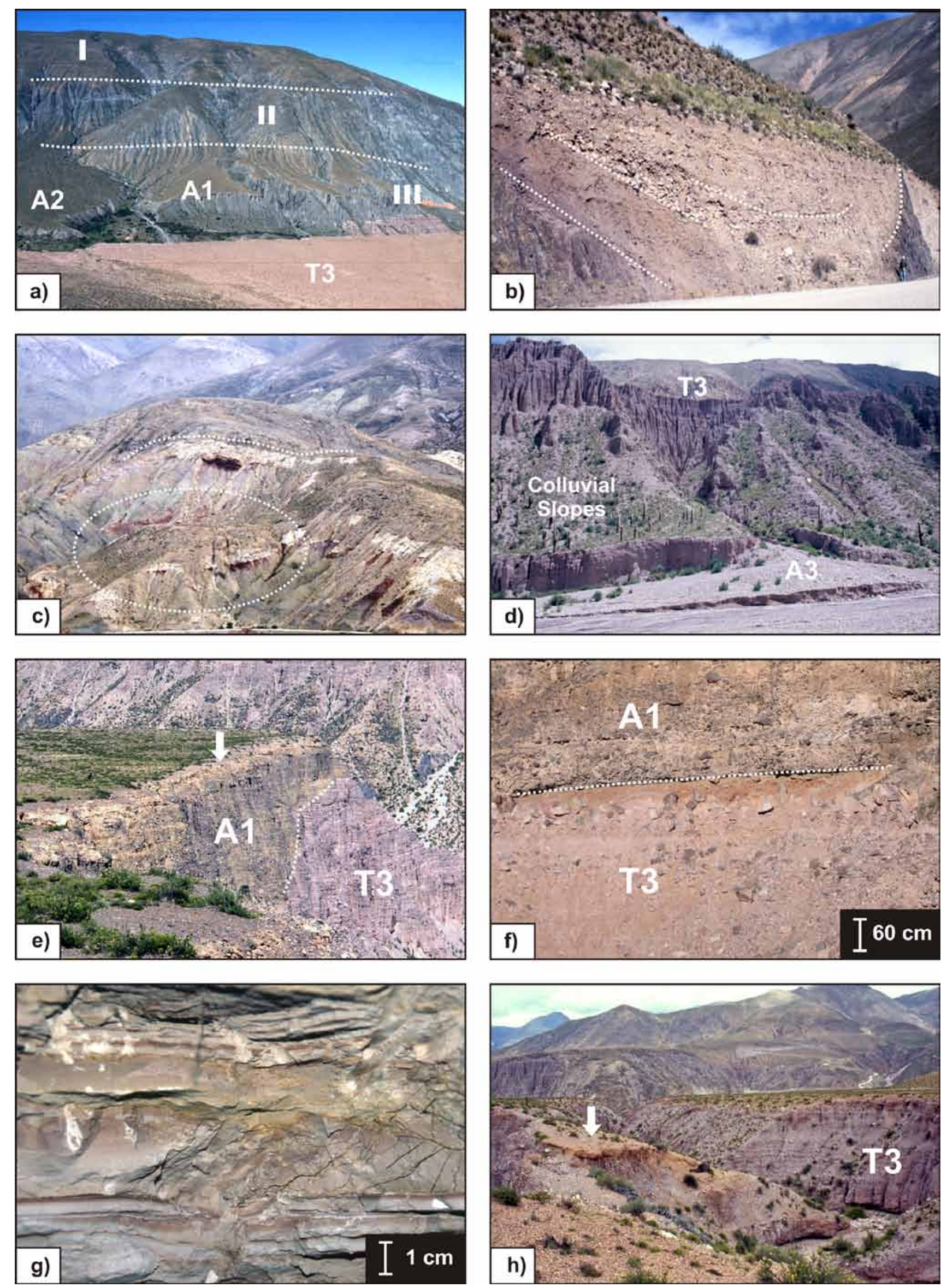
iii) Several depositional landforms including alluvial fans, terraces and colluvial debris cones constitute the transition from the slope segments to past and present floodplains. Three different generations of alluvial fans have formed at the toes of the larger slope channels and were distinguished in the study area based on their topographic and morphological characteristics (MAY 2008). The oldest generation A1 comprises clearly inactive and frequently dissected alluvial fans of different sizes adjusted to inactive terrace surfaces (Fig. 2a). As evident from surface texture, color and debris flow levees, depositional processes are still active on alluvial fans of the second generation A2 (Fig. 2a). However, erosional scarps along the fan toes indicate that the main phase of their construction was interrupted at least once by the dominance of floodplain activity over alluvial debris flow processes on the fans. The initiation of alluvial fan deposition of A1 and A2 fans may have commenced synchronously while retrocedent incision progressed up the valley, lowering the base-level and ultimately leading to the inactivity and dissection of most A1 fans. A3 generation fans are relatively small landforms which actively contribute sediment onto the modern valley floor predominantly by debris flow processes (Fig. 2d).

The most characteristic landforms in the Quebrada de Purmamarca are three well-preserved levels of depositional terraces (MAY 2008). The two higher levels T1 and T2, which have preserved only at one location in the study area, are inclined $\sim 5.5-7^{\circ}$ towards the ESE. Segments of the lower terrace level T3 with an average elevation of $\sim 90 \mathrm{~m}$ above the valley floor and mean inclinations of $\sim 3-5^{\circ}$ have preserved at several locations and can be topographically correlated to each other (TCHILINGUIRIAN \& PEREYRA 2001; MAY 2002). Up to $40 \mathrm{~m}$ deep $\mathrm{v}$-shaped valleys have incised into the terrace levels $\mathrm{T} 1$ and $\mathrm{T} 2$. Their asymmetrical cross-sections most likely owe to subsequent reshaping by periglacial processes. In contrast, the surface of terrace T3 shows dissection by narrow, meandering channels of up to $\sim 15 \mathrm{~m}$ depth implying a relatively young erosional history compared to the older terrace levels. Along the terrace rims the formation of well-developed badlands includes a variety of erosional landforms such as earth pyramids and organ pipes and is related to the removement of finer particles from the unconsolidated terrace deposits by wash and sheetflow processes during strong precipitation events (KüHN 1924; FoCHLER-HAUKE 1952; BECKER 1966). Laterally continuous, concave slopes of $\sim 35^{\circ}-45^{\circ}$ inclination have formed at the transition between the badlands and the modern floodplain (Fig. 2d), and are interpreted as colluvial debris cones or slopes formed by gravitational processes. At their toes, these colluvial deposits show a pronounced scarp of several meters height, likely resulting from lateral erosion under conditions of enhanced floodplain activity. Today, these debris cones are mostly inactive features covered by vegetation and actively dissected by gullies, which discharge into A-3 alluvial fans.

Table 1 : Summary of lithofacies classification and interpretation for the sedimentary profiles in the Quebrada de Purmamarca (see Fig. 3 and text for details). Tabelle 1: Zusammenfassung der Klassifizierung der Lithofazies und deren Interpretation für die Sedimentprofile in der Quebrada de Purmamarca (siehe Abb. 3 und Text für Details).

\begin{tabular}{|c|c|c|c|c|c|c|c|}
\hline Name & Matrix & $\emptyset$ Event & Clast Max $[\mathrm{cm}]$ & Clast Ø & Clast Shapes & Other & Interpretation \\
\hline D1 & + & 150 & $80-120$ & 10-20 & Subang. - Subrd. & - & Debris-flow [ Mud Flow] \\
\hline D2 & - & 150 & 100 & 10-20 & Subangular & Coarsening up & Debris-flow \\
\hline D2X & - & > 200 & 150-200 & $30-50$ & Angular - Subang. & & Rock avalanche [?] \\
\hline D3 & - & 100 & 30 & 15-20 & Ang. - Subang. & & Debris-flow [ Grain Flow] \\
\hline D4 & - & $<100$ & $5-10$ & $5-7$ & Subang. - Round. & Fining up & Water-Laid Sheet flow ?? \\
\hline $\mathbf{F}$ & l & $<100$ & Cobbles & $1-5$ & Subang. - Round. & Fining up & Fluvial \\
\hline $\mathbf{L}$ & l & $<100$ & Clay - Sand & - & - & Coarsening up & Lacustrine \\
\hline
\end{tabular}

\section{2. Sedimentology and stratigraphy of valley fills}

Most exposed Quaternary terrace and fan deposits in the Eastern Cordillera of NW Argentina are summarized within the 'Purmamarca' and 'Maimará' Formations (RAmos, Turic \& ZuZeK 1967; Turner 1970; SAlfity ET AL. 1984; SEGEMAR-ITGE 1998). Dominant sediments are loosely classified as coarse clastics (Fochler-HAUKe 1952; VIERS 1967; WERNER 1984; MAY 2008), but were also referred to as fanglomerates (Ramos, Turic \& ZuzeK 1967; Amengual \& ZanetTini 1974) or conglomerates (KüHN 1924; SEGEMAR-ITGE 1998; RoBINSON ET AL. 2005; SANCHO ET AL. 2008). In the Quebrada de Purmamarca the sediments building the higher terrace levels T1 and T2 are not as well exposed, but seem to exhibit a more complex internal sedimentary architecture, possibly as the result of repeated erosional and depositional cycles. In contrast, vertical exposures of $>100 \mathrm{~m}$ height along the rims of terrace level T3 and alluvial fan generation A1 pres- ent sedimentary evidence for the depositional processes responsible for their construction (Fig. 2e, f, h). Seven lithofacies were distinguished (MAY 2002), mainly based on criteria used in existing classifications for alluvial fan and braided river sediments (Table 1; NEMEC \& STEEL 1984; Table 1; BLAIR \& McPherson 1994; Milana 1994; Miall 1996).

Most of the sediments involved (Table 1: D1 - 4) can be attributed to non-erosive debris flow events or hyperconcentrated flows typical for proximal to medial alluvial fan environments (Lowe 1979; Costa 1984; BlaIr \& McPHerson 1994). Owing to maximum clast sizes of up to $200 \mathrm{~cm}$ and thicknesses of $>200 \mathrm{~cm}$, D2X sediments could alternatively be interpreted as the result of rock slides or rock avalanche events commonly observed in proximal alluvial fan settings (Blair \& McPherson 1994). Locally, debris flow sediments are intercalated with thin layers of fluvial sands or pebbles indicating reworking processes on the floodplain. At some locations, however, fluvial sediments can reach thicknesses 
of several meters and are often associated with silts and clays of lacustrine origin (Table 1: F, L). The lacustrine sediments frequently contain laminated rhythmites of highly variable thickness and thereby reflect strong seasonal and interannual changes in discharge and sediment input to perennial shallow lakes which must have existed for several years to more than decades (Fig. 2g). In combination, these fluvial and lacustrine sediments reflect local low-energy deposition within an otherwise high-energy sedimentary environment (HARvey 1997).

From the stratigraphical association of the documented profiles a pronounced paleotopography must have formed the base for the deposition of terrace T3 as some profiles rest unconformably on bedrock while others do not have their base exposed. That implies that the last major phase of erosion and downcutting must have incised to a level below the present valley floor, and the approximate thickness of valley fill below the modern floodplain has been estimated to 30-40 m based on geophysical reconnaissance (personal communication R. Kleine-Hering).

Overall comparison of the profiles reveals two sedimentary units of different colours which are assumed to reflect differences in lithological composition (Fig. 2e, 3). The lower sedimentary unit (unit I) appears greyish-pinkish (Fig. 2e\&f; Munsell 5YR 6/3) in all the profiles throughout the study area pointing to a large, common and constant catchment with high yields of pinkish Cambrian quarzites, possibly as the result of extensive production of frost debris. Although both units are characterized by common sedimentary patterns and lithofacies, the upper sedimentary unit (unit II) varies in colour from profile to profile reflecting alluvial deposition of lithologies originating from much smaller, local catchments. Based on topographic and geomorphological mapping (MAY 2008), the unit I can be attributed to the basin-wide deposition of terrace T3, whereas unit II represents the deposition of alluvial fan generation A1 from different smaller catchment areas.

Fluvial and lacustrine sediments are restricted to unit I and the interface between the units. They may be interpreted as the result of reduced floodplain activity and blocking by lateral sediment input such as debris flows or landslides (Costa \& Schuster 1988), but no landslide or other significant deposits have been found in close association with the lacustrine deposits. The local occurrence of low-energy environments is characteristic for debris flow controlled floodplains (HARvey 1997). Synchronous and catchmentwide occurrence of low-energy environments could therefore point to a temporal decrease in debris-flow frequencies resulting from subtle shifts with regard to discharge and sediment supplies. Between adjacent profiles, lithofacies $\mathrm{L}$ and $\mathrm{F}$ are frequently found at similar elevations above the modern floodplain and can stratigraphically be correlated (Fig. 3), suggesting the occurrence of at least two intervals of enhanced conditions for low-energy deposition within the overall deposition of the T3 terrace. Importantly, fluvial and lacustrine sediments separate the two sedimentary units at several localities, thereby announcing a marked change in hydrological conditions and/or sediment supplies morphologically reflected by the switch from terrace T3 deposition towards alluvial fan generation A1. This change is roughly dated by a single radiocarbon date of $49550 \pm 1700$ uncalibrated $14 \mathrm{C}$ years BP, which was

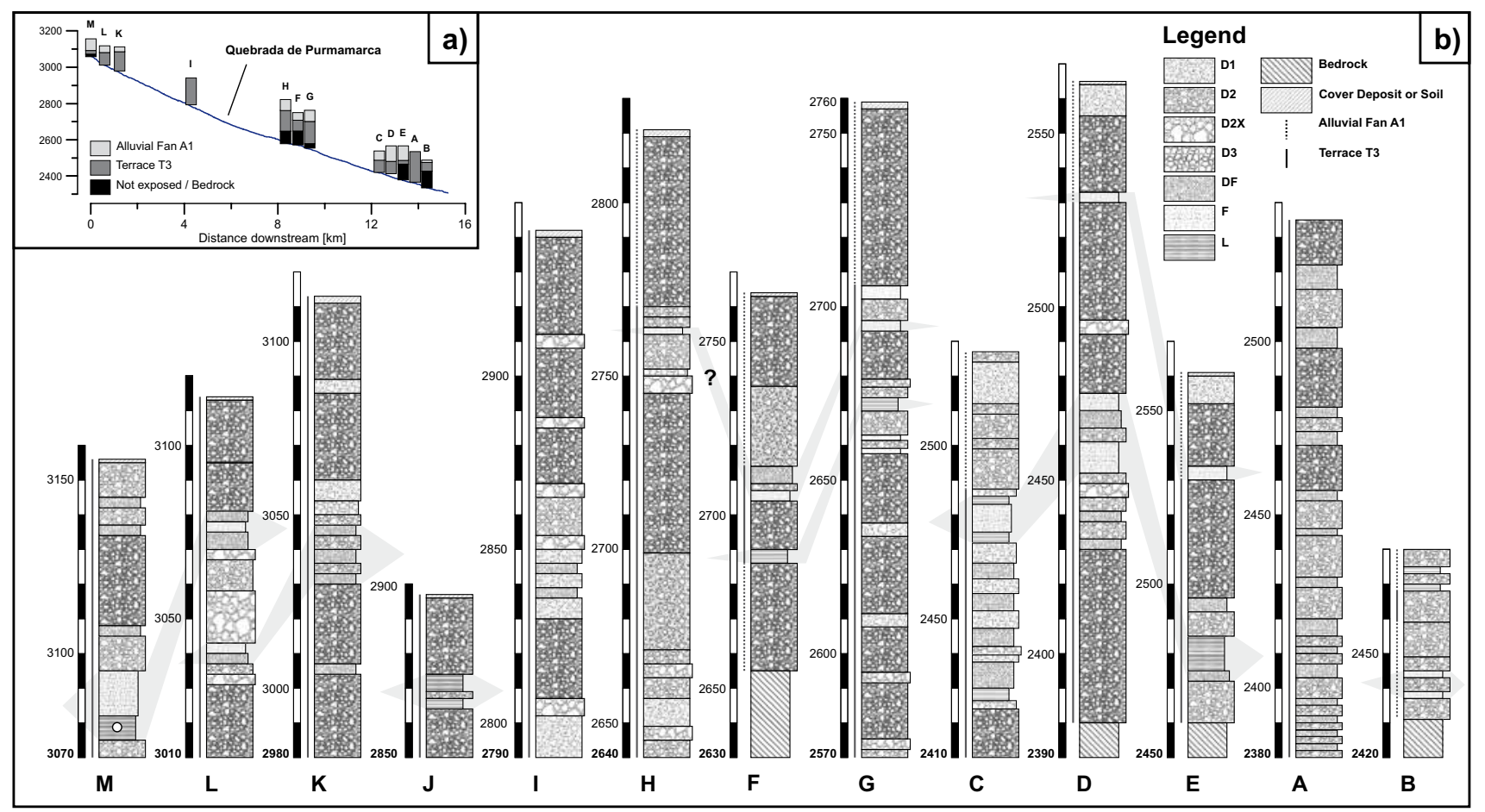

Fig. 3: Sedimentary profiles along the Quebrada de Purmamarca. a) Location along a longitudinal stream profile. b) Detailed sedimentary profiles and correlation (grey) of intercalated fine-grained sediments between adjacent profiles; the circle marks the $14 \mathrm{C}$-age of $49550 \pm 1700 \mathrm{yr}$ BP and letters refer to the profile locations in Fig. 1.

Abb. 3: Sedimentprofile entlang der Quebrada de Purmamarca. a) Lage entlang des Längsprofiles. b) Detaillierte Sedimentprofile und Korrelation (grau) der eingeschalteten Feinlagen zwischen den benachbarten Profilen; der Kreis kennzeichnet das 14 C-Alter von $49550 \pm 1700$ yr BP und Buchstaben beziehen sich auf die Lage der Profile in Abb. 1. 


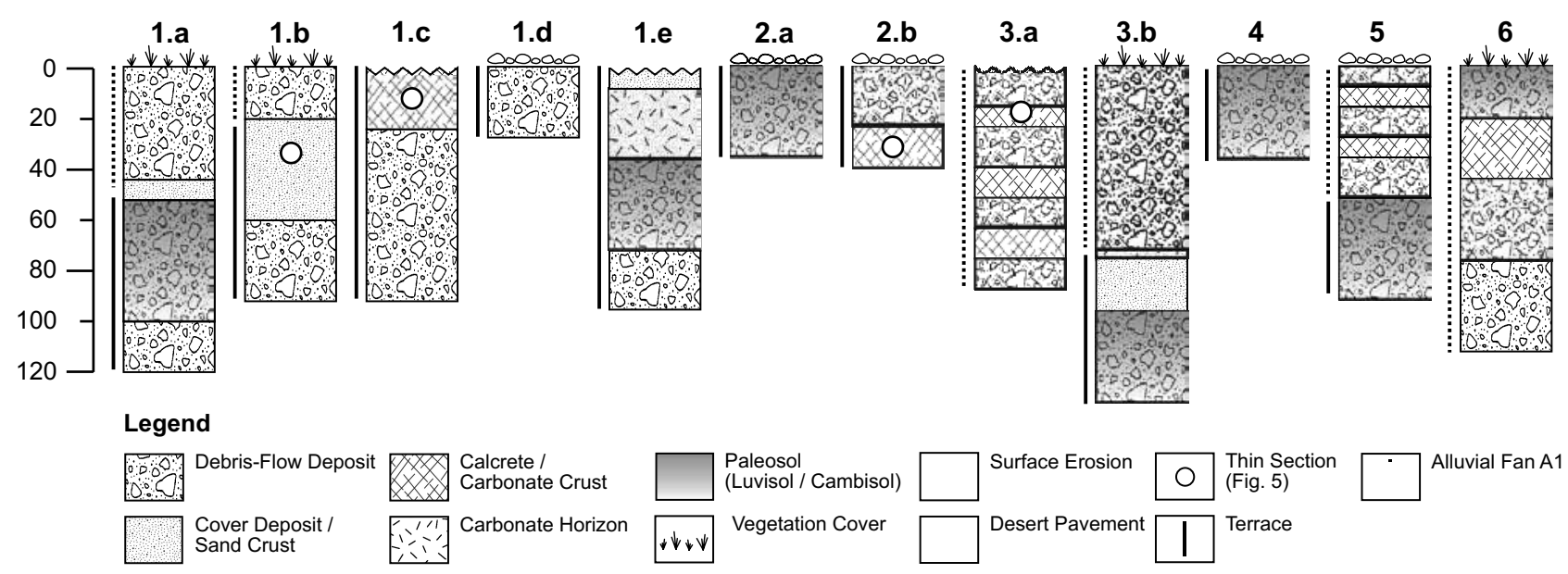

Fig. 4: Summary of the excavated pits and exposures on terrace and alluvial fan surfaces (numbers refer to the profile locations in Fig. 1). Abb. 4: Zusammenfassung der Profile und Aufschlüsse auf Terrassen- und Schwemmfächeroberflächen (Nummern beziehen sich auf die Lage der Profile in Abb. 1).

obtained by AMS dating of plant remains extracted from lacustrine sediments in the upper catchment (MAY 2002).

\subsection{Paleosols and cover deposits}

Varying with topographical setting, underlying lithologies and microclimatic conditions, the modern surface soils within the study area are usually very shallow, and weakly developed soils. The associated pedogenic processes range from initial calcrete formation (powder calcrete) on Precambrian phyllites in the lower and drier catchment to rubefication and oxidation within the debris covered slopes of the higher catchment (MAY 2002). At several localities, 20-40 cm thick and reddish horizons of elevated clay content were observed within the coarse clastic terrace deposits and interpreted as $\mathrm{B}_{\mathrm{v}}$ horizons of well developed cambisols. Sometimes, these horizons show macroscopic clay coatings and thereby classify as Bt horizons of luvisols. Both horizons are indicative of advanced pedogenesis and were observed exclusively on terraces surfaces (WERNER 1971, 1984; TCHILINGUIRIAN \& Pereyra 2001). However, these $B_{t}$ or $B_{v}$ horizons are frequently truncated by erosion or deflation and formation of desert pavements (Fig. 2f, 4), or were buried by deposition of clastic sediments such as the debris flow deposits of alluvial fan generation A1 (Fig. 2f). In both cases, their relict or fossil character likely reflects increased geomorphic stability under significantly more humid environmental conditions in the past.

Frequently, the terrace surfaces are directly overlain by a layer of sandy deposits of marked erosional resistivity which traces a pre-existing topography (Fig. 2h) and has not been found anywhere below the terrace level. At some locations, these deposits are buried by prograding alluvial fan deposits (Fig. 4). The sand deposits show no apparent internal stratification and can reach thicknesses of several meters. They are predominantly composed of cemented fine to medium sand and contain floating clasts of various grain sizes up to $\sim 15 \mathrm{~cm}$. Their highest thickness is reached in topographically protected settings below rims or channel banks or along east exposed slopes, probably pointing to their aeolian origin. In thin section, the sand crust ex- hibits a clast supported fabric of subangular to subrounded clasts, well sorted fine and middle sand (Fig. 5a). Several subangular larger clasts and rock fragments are supported by the sand mass. The sample shows many larger pore spaces. Small amounts of cryptocrystalline orange matrix material can be observed between the clasts, possibly resulting from a weak illuviation of hematite-rich clays. Based on their topographic setting and their macroscopic and microscopic sedimentary characteristics these sand crusts may be interpreted as fluvio-aeolian cover sands subsequently hardened by desiccation.

Several types of relict soil horizons with particularly high $\mathrm{CaCO}_{3}$ content of up to $60 \%$ have been documented in the study area. Most of these horizons are cemented and can thereby be classified as calcretes (GoudIE 1983; WRIGHT \& TuCKER 1991). Particularly on the higher terrace levels (T1 and T2) they are developed as thick hardpan calcretes and should be associated with the truncation of a former, well developed paleosol. Micromorphological analysis of a hardpan calcrete on top of terrace T2 shows few rock clasts and well-rounded mineral fragments supported by a light cryptocrystalline carbonate matrix pointing to a mature stage of carbonatization (Fig. 5a). The very fine and dense matrix is interspersed with particularly rounded and smooth voids and fissures indicating subsequent solution processes and karstification. Frequently, the voids are surrounded by spheres of dark mottles interpreted as the result from manganese precipitation, possibly in relation to increased water saturation and carbonate solution. Voids and fissures are partly filled by a whitish, moderately fine carbonate matrix (crystallaria). These results point to a long phase of carbonatization which was interrupted by a phase of solution and hydromorphy before returning to ongoing carbonatization under current conditions.

In addition, stacked and partly cemented calcrete horizons are frequently exposed along the rims of A1 alluvial fans where they have formed within clastic debris flow deposits of dominantly Precambrian phyllite lithologies (Fig. 2e). Given this apparent relation to lithology, carbonate may be the product of phyllite weathering and reprecipitation of carbonate saturated interflow within the inclined and lay- 

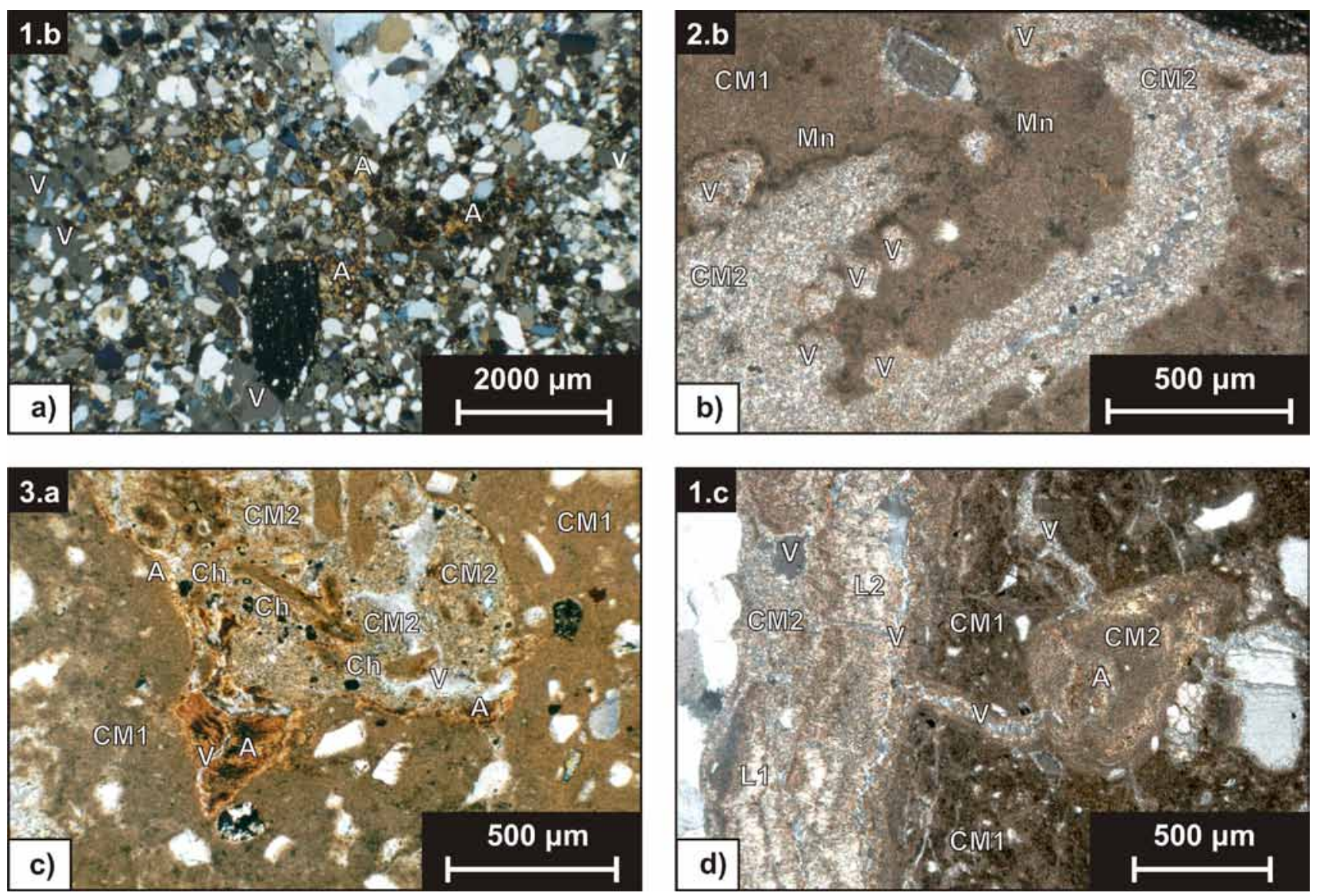

Fig. 5: Micromorphological thin sections of sandy cover deposit (a) and calcretes (b-d). V-void, A - argillans, CM - carbonate matrix, Mn - manganese mottles, Ch - charcoal / organic material, L - laminar coating (black boxes in upper left corner denote sample location in Fig. 4).

Abb. 5: Mikromorphologische Dünnschliffe der sandigen Decksedimente (a) und Kalkkrusten (b-d). V-Pore, A - Toncutane, CM - Karbonatische Matrix, Mn - Manganfleckung, Ch - Kohlepartikel / Organik, L - laminare Überzüge (schwarze Kästchen in Ecke linksoben kennzeichnet die Lage der Proben in Abb. 4).

ered fan sediments, as observed under modern environmental conditions (WERNER 1971; SCHEFFER \& SCHACHTSCHABEL 2002). In this context, partly cemented calcrete horizons were infrequently observed on the T3 terrace surface associated to lines of drainage such as gullies (Fig. 4). The thin sections of these calcretes show a dense, dark and cryptocrystalline carbonatic matrix interspersed with several cracks and containing abundant angular to little rounded rock and mineral fragments as typical for moderately developed calcretes (Wright \& Tucker 1991). Partly, well developed orange coloured argillans have formed along the voids and crack walls. Generally, these argillans, but also parts of the dark carbonatic matrix, are split into fragments, partly filling the cracks. Otherwise, a lighter carbonatic matrix is forming within the voids and cracks, mantling rock and mineral fragments as well as fragments of the dark matrix, and forming laminae around the larger rock clasts. Multiple opaque dots may be interpreted as charcoal and/or organic material. Based on these observations, carbonatization has taken place in at least two distinct phases and was locally interrupted by clay illuviation and an interval of subsequent fragmentation possibly related to desiccation.

\section{Discussion}

The results from the geomorphological, sedimentary and paleopedological analysis and observation in the Quebrada de Purmamarca are summarized in Fig. 6. They form the base for the reconstruction of a regional Late Quaternary landscape evolution and their paleoenvironmental interpretation. Landscape evolution and the discussion of causes for geomorphic change are tentatively divided into two different timescales: i) longer-term changes expressed by different terrace levels and corresponding to cut-and-fill cycles likely driven by complex climate and tectonic interactions, and ii) short- to medium-term climate and environmental changes leading to subsequent terrace incision, deposition of alluvial fan generations, colluvial debris cones, and the formation of paleosols and cover deposits.

i) Three distinct levels of depositional terraces were documented in the Quebrada de Purmamarca. Depositional terraces have been reported from several sites in the Eastern Cordillera of NW Argentina and reflect repeated cycles of alternating erosion and aggradation (HILLEY \& STRECKER 2005). Two major regional terrace levels were reported by TCHILINGUIRIAN \& PEREYRA (2001) along the western side of the Quebrada de Humahuaca, the lower being equal to level T3, and the higher likely corresponding to the terrace levels T1 and T2 in the Quebrada de Purmamaca. Four main depositional terrace levels were examined and sampled by RoBINSON ET AL. (2004) at the Río de la Huerta along the eastern side of the Quebrada de Humahuaca, whereas only three major terrace levels were mapped by WERNER (1984) at the same site. Up to six depositional levels were distinguished at the Tilcara fan (AzArevich ET AL. 1999; SANCHO ET AL. 2008). Thus, the topographic correlation of the terraces proves dif- 


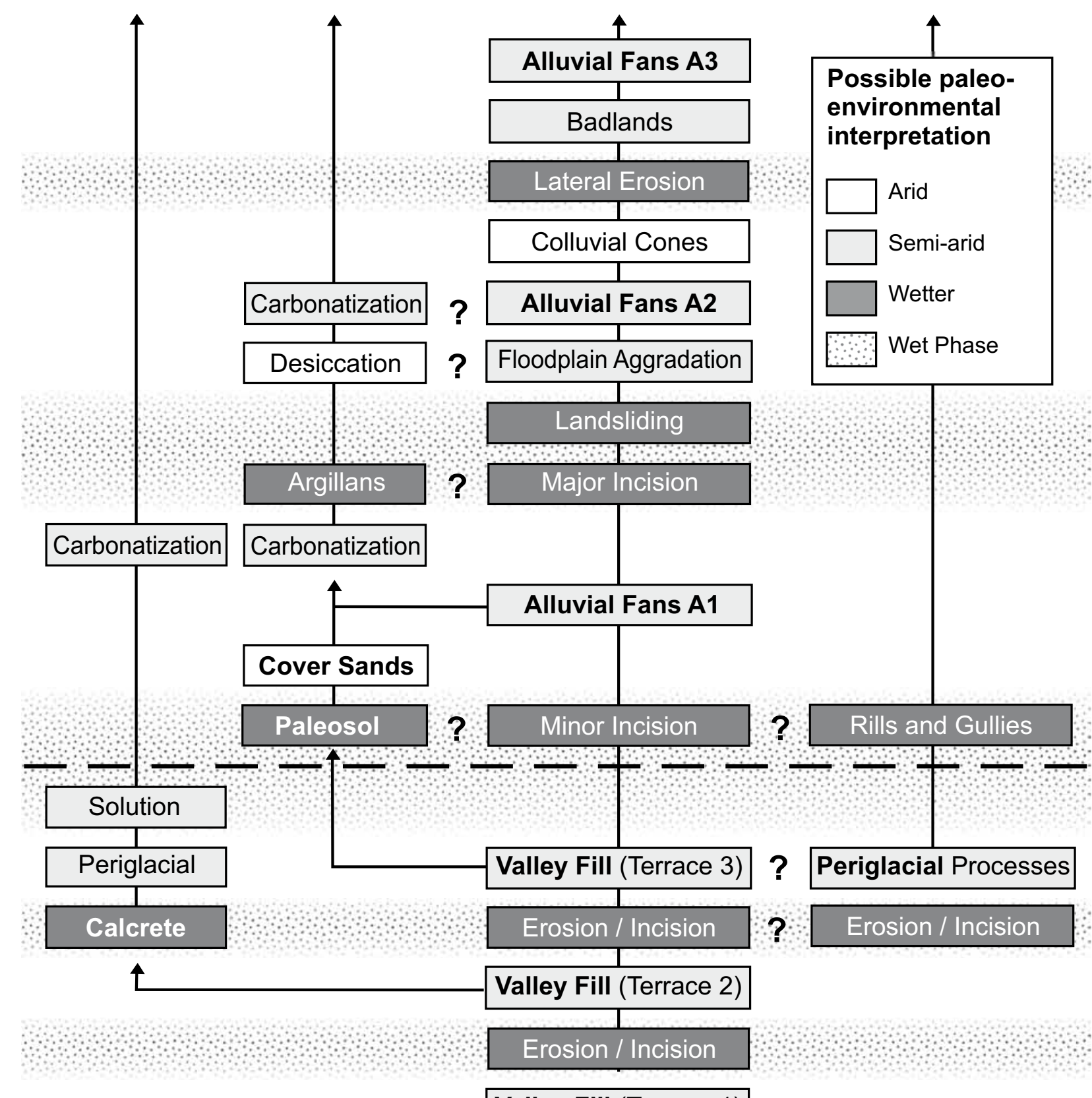

Valley Fill (Terrace 1)

TIME

TERRACE SURFACES

VALLEY

SLOPES

Fig. 6: Schematic summary, and tentative correlation and timeframe for the observed geomorphic, sedimentary and paleopedological data in the Quebrada de Purmamarca. Dashed line indicates radiocarbon age ( ${ }^{*}$ see discussion for details).

Abb. 6: Schematische Zusammenfassung, und vorläufige Korrelation und Zeitrahmen für die beobachteten geomorphologischen, sedimentären und paläopedologischen Befunde in der Quebrada de Purmamarca. Gestrichelte Linie kennzeichnet 14 C-Alter ( ${ }^{*}$ siehe Diskussion für Details).

ficult, particularly across major fault lines such as the Quebrada de Humahuaca. As modelled for the Quebrada de Toro by Hilley \& STRECKER (2005), regionally asynchronous terrace chronologies probably express the participation of tectonics as the dominant control on regional base-levels and stream power on longer temporal scales. Within the study area, the comparatively old ages and steeper slopes of the higher terraces T1 and T2 deduced from the geomorphological observations also corroborate minor tectonic movements during the time of their deposition. In this context, the onset and duration of the last cut-and-fill cycle responsible for the deposition of the largely undeformed terraces throughout the Eastern Cordillera may broadly coincide with the last major uplift and deformation event in the Eastern Cordillera around 1 Ma ago (SAlfity ET AL. 1984; HernándeZ, ReYNOlds \& Disalvo 1996; Marrett \& Strecker 2000; Hilley \& STRECKER 2005).

Oscillations between incision and aggradation are the result of significant changes in sediment supplies and/or discharge over time (KNighton 1998; Schumm 2005). Particularly over shorter timescales, these changes likely owe to changes in past precipitation frequencies and magnitude, and are ultimately expressed in changing stream powers of discharge or flooding events (BuLl 1979, 1988). In the study 
area, a pronounced paleotopography has been covered by periglacial sediments and terrace deposits and can be interpreted to reflect an extensive phase of increased stream power preceding the onset of T3 deposition and likely pointing to more humid and/or warmer environmental conditions than thereafter. In contrast, the sedimentary profiles within the T3 terrace reveal debris-flows as the dominant depositional process with only minor participation of low-energy fluvial and lacustrine processes. The intercalated rhythmites show evidence for a strong prevailing seasonality as well as interannual variability during the time of deposition. Although debris-flow deposition also characterizes modern morphodynamics in the Quebrada de Purmamarca (CENCETTI, RIVELli $\&$ TACCONI 2006), the observed thickness and large clast sizes typical for the terrace T3 deposits imply i) high-magnitude storm and flood events under generally arid or semi-arid conditions, and ii) a much more efficient mode of clast production than today, e.g. due to strong physical weathering by frost processes. These characteristics, association and co-existence of all observed lithofacies are commonly interpreted as typical for proximal alluvial fan environments (BLAIR \& MCPHERSON 1994; HARVEY 1997) and a very proximal intersection point related to the reduction of fluvial processes under semi-arid to arid and likely colder glacial environmental conditions (Weissmann, Mount \& FoGG 2002).

Here, the available data from the upper study area provides evidence for an intense past production of mainly quartzitic frost debris by periglacial processes and a maximum past depression of the periglacial belt of $\sim 1000-1300 \mathrm{~m}$. Assuming temperature gradients of $0.5-0.6^{\circ} \mathrm{C}$, this corresponds to a temperature reduction of $\sim 5-8^{\circ} \mathrm{C}$ and corroborates other estimates for past temperature reduction in the Central Andes of NW Argentina (GARlefF \& STINGL 1985; Garleff et Al. 1991; Abraham de VAzQuez et Al. 2000; Ahumada 2002). As a consequence, the spatial extent of surface being subject to the cryogenic production and downslope transport of frost debris increased to $\sim 80 \%$ of the catchment area compared to $\sim 10-25 \%$ today (Fig. 1). For the fluvial system of the Quebrada de Purmamarca this must have implied a significant (up to 8-fold) multiplication of sediment supply. An increased participation of frost generated clasts of Cambrian quartzites is evident from the basin-wide pinkish colour of the terrace deposits. In most sedimentary profiles, two intervals of dominant fluvial and lacustrine sediments were observed and may thereby imply two phases of more stable (humid) environmental conditions and reduced debris-flow frequencies (Fig. 3). In most of the study area below 2800-2900 $\mathrm{m}$ asl, the upper of the two intervals divides T3 terrace deposits from A1 alluvial fan deposits characterized by local lithologies, whereas above $\sim 2900 \mathrm{~m}$ asl T3 sedimentation seems to prevail longer. A radiocarbon date on plant remains of $49550 \pm 1700{ }^{14} \mathrm{C}$ a BP is available from this upper interval, and corresponds well to an OSL age of $47.6 \pm 2.8$ ka taken at the same site (RoBINSON ET AL. 2005). Therefore, this age is interpreted to coincide with the gradual transition to A1 alluvial fan deposition, which started in the lower study area and reached elevations above $\sim 2900 \mathrm{~m}$ asl some time after $50 \mathrm{ka}$ ago. Most of the so far published OLS ages from comparable valley fill deposits plot into an interval between $\sim 45-95 \mathrm{ka}$ and may thus provide a preliminary estimate for the timing of the last terrace deposition (RoBINSON ET AL. 2005; SANCHO ET AL. 2008; SPENCER \& RoBINSON 2008). In fact, cold temperatures before $\sim 50 \mathrm{ka} B P$ in northern Argentina are also reported from studies of loess and glacial deposits (CARIgnANO 1999; ZIPPRICH ET AL. 2000) and support the scenario of temperature changes, likely in relation to the last cycle of global glaciation, as a critical control on sediment supplies and thus the course and ending of debrisflow dominated valley filling in the Eastern Cordillera of NW Argentina.

ii) As evident from the almost vertical walls of the $>100 \mathrm{~m}$ high T3 terrace, a severe and pronounced phase of incision must occurred after the end of terrace deposition. The exact onset of incision is difficult to constrain and could have postdated the onset of alluvial fan deposition considerably. In this case, retrocedent incision may have slowly extended headward once decreasing sediment supplies fell below a threshold resulting from the upward shift of the periglacial belt, leading to a time lag and eventually the dissection of slopes and A3 fans. The onset and intensity of incision could have been additionally amplified once the drainage system had re-established and the frost debris previously stored on the extensive slopes of the upper study area was exhausted (Pratt ET Al. 2002). Again, in this scenario temperature changes and the related changes in sediment supply are the main drivers for incision and do not require a substantial increase in precipitation. However, the Quebrada de Purmamarca incision reached well below the level of the modern floodplain. Several documented landslide deposits provide additional evidence for an overall intensive and fast incision event not allowing for the gradual adjustment of slopes (MAY 2008). The oversteepening of valley slopes by rapid incision as well as the evacuation of large quantities of sediment into the Andean foreland probably required significantly increased precipitation amounts and wetter environmental conditions (TRAUTH \& STRECKER 1999; TRAUTH ET AL. 2000; Trauth ET AL. 2003; Hermanns \& SchellenberGER 2008), although increased landslide frequencies may have been triggered by tectonic events (HERMANNS \& STRECKER 1999; Strecker \& MARRETt 1999; HeRMANNS ET AL. 2001). In fact, significant changes in monsoonal precipitation throughout the last 1.1 Ma were deduced from sequences of alternating loess and paleosols at Tafí del Valle (Schellenberger 2006; SCHELlenBerger \& VeIt 2006) and potentially trigger manifold increases in sediment transport rates (BoOKHAGEN, ThIEDE \& STRECKER 2005).

The particularly well developed paleosol on top of the terrace surfaces may be interpreted as evidence for wetter climates following the end of terrace deposition, possibly also causing increased stream powers and the onset of incision. The occurrence of reddish and argillic paleosol horizons on terrace surfaces has been reported throughout the Quebrada de Humahuaca and is often associated with petrocalcic B- and C-horizons (SEGEMAR-ITGE 1998; ZIPPRICH ET AL. 2000; TCHILINGUIRIAN \& PEREYRA 2001). ZIPPRICH ET AL. (2000) provide two radiocarbon dates of $27.97 \pm 0.2$ and 15.84 $\pm 0.1{ }^{14} \mathrm{C}$ a BP from calcrete horizons as estimates for the timing of soil formation. Assuming regional synchrony, these different paleosol horizons may indicate two widespread regional wet phases roughly before $32 \mathrm{cal} \mathrm{ka} \mathrm{BP}$ and $19 \mathrm{cal} \mathrm{ka}$ BP. First OSL ages from loess-paleosol-sequences in Tafí del 
Valle provide additional evidence for an important phase of soil formation before $\sim 33 \mathrm{ka}$ (KEMP ET AL. 2004). In the study area, the paleosol is frequently overlain by alluvial fan deposits (Fig. 2f). This implies that alluvial fans on top of the terrace surfaces were still active during or even after paleosol formation. Thus, the major phase of incision responsible for the significant lowering of the valley floor and the dissection of most A3 alluvial fans, most likely postdates paleosol formation.

Several observations from the Quebrada de Purmamarca contribute to the idea of pronounced and shorter-term changes of moisture supply in NW Argentina significantly postdating the formation of the well developed paleosol. At many places in the study area the paleosol is directly overlain by cover sands probably owing to aeolian activity and fluvial reworking (Fig. 5). These cover sands have accumulated along the slopes of slightly incised channels and should therefore postdate a first, minor phase of incision, which could coincide with the formation of the paleosol under more humid environmental conditions. Similar aeolian cover sands were recently dated to $39.4 \pm 2.3 \mathrm{ka}$ by OSL in the Quebrada de la Huerta (RoBInson eT AL. 2005; SpEnCER \& RoBINSON 2008). Thus, the cover sands may tentatively indicate the onset of enhanced aridity, increased wind speeds and loess-like aeolian transport from the Puna plateau into the protected valleys of the Eastern Cordillera until $\sim 40 \mathrm{ka}$ $\mathrm{BP}$, similar to processes observed in reduced intensities today (Greeley, Christensen \& Carrasco 1989; Tchilinguirian \& Pereyra 2001). These cover sands are found exclusively on top of the T3 terrace surface and are at many places eroded or covered by debris flow deposits of inactive A1 alluvial fans (Fig. 2h, Fig. 4), pointing to significant alluvial and fluvial activity after sand deposition. In many ways, this could be interpreted as evidence for a two-phased erosion and incision process. In this context, many authors have reported a particularly wet climatic interval throughout most of the Central Andes during lateglacial times referred to as the Tauca phase (Argollo \& Mourguiart 2000; BAKer ET AL. 2001; Fritz et Al. 2004; Placzek, Quade \& PAtchett 2006), which could have caused the second, major pulse of incision in the Quebrada de Purmamarca. This scenario is corroborated by several, partly cemented non-pedogenic calcrete horizons, which are intercalated with A3 alluvial fan sediments. Based on their micromorphology, they form on surfaces of favourable lithological and hydrological conditions. Carbonatization, however, was interrupted at least once by more humid environmental conditions characterized by clay illuviation. Therefore, alluvial fans and carbonatization probably reflect semi-arid environmental conditions similar to today, whereas terrace incision and the formation of well developed paleosols on top of the terraces probably required significantly elevated precipitation, discharge and moisture availability.

After floodplain aggradation and alluvial fan deposition had elevated the floodplain approximately to its present level, several minor geomorphic and paleoenvironmental changes are evident from the geomorphology along the terrace footwalls, where colluvial debris cones and slopes have formed and are now dissected by younger incision associated to A3 alluvial fan activity and the ongoing formation of badlands. At their toes, the colluvial debris slopes show a pronounced scarp as related to lateral erosion and enhanced floodplain activity. Thereby, these colluvial slopes constitute evidence for both decreased floodplain activity and largely restricted alluvial fan and badland processes, pointing to overall particularly dry environmental conditions in the more recent past. Possibly, the accumulation of colluvial material coincides to an interval of marked aridity during the Mid-Holocene reported from NW Argentina (FERNÁNDEZ 1984; Markgraf 1985; Alcalde \& Kulemeyer 1999), also known as the "archaeological silence" and the absence of essential human occupation (FernÁNDEZ ET AL. 1991; KulEMEYer ET AL. 1999; YACoBAccio \& Morales 2005). Finally, the return to less arid conditions in the Late Holocene may have re-established the ongoing degradation of terrace slopes by badland formation, debris flow processes and alluvial fan A3 deposition, and floodplain aggradation (KULEMEYER 2005; LUPO ET AL. 2006). Whether this tendency ultimately reflects increased sediment supplies following increased human interference (Aguero 1986; Cencetti, Rivelli \& TAcconi 2006) or is the result of variations in climatically controlled short-term variability of precipitation frequencies and magnitudes (MAas et Al. 1999; Prieto, Herrera \& Dussel 2000) can not be decided on the base of the available data.

\section{Conclusions}

The documentation and interpretation of geomorphic, sedimentary and paleopedogenic data in the Quebrada de Purmamarca has allowed the reconstruction of a dynamic Late Quaternary landscape evolution. Over longer Quaternary timescales, the accumulation and evacuation of large quantities of material is regarded the dominating geomorphic process in the intramontane valley of the Eastern Cordillera, leading to the formation of terrace systems. As elsewhere in the Andes of NW Argentina, the timing and rates of these cut-and-fill cycles in the Quebrada de Purmamarca are likely controlled by a complex interplay between tectonics and climatic factors. In particular, the severe temperature-driven depression of the periglacial belt seems to have imposed an important control on longer to medium-term catchment denudation through an intensified production of coarse debris. A well developed paleosol and the formation of alluvial fans may indicate somewhat less cold a dry environmental conditions after $\sim 50 \mathrm{ka}$. The onset of a major incision event significantly postdates the end of valley filling and could have been caused by a marked increase in monsoonal precipitation during the Late Glacial. Holocene humidity changes are probably responsible for the formation of several minor inactive landforms along the modern valley floors and paleopedogenic features on terrace surfaces.

Future work should concentrate on the regional extension and comparison of the observed data. Particularly the combination of sedimentary and paleopedogenic approaches like mapping and the detailed micromorphological analysis of paleosols should have the potential to produce an enormous amount of new information with regard to Late Quaternary humidity changes. A thorough knowledge and spatial mapping of landforms and sediments is also the base for quantitative modelling of longer to medium-term denudation and erosion rates (e.g. HILLEY \& STRECKER 2005). In addition, further efforts aiming at the establishment of an absolute chron- 
ological framework are urgently needed to test the relative importance of tectonic verse climatic controls in longer-term basin history. Here, optically stimulated luminescence (OSL) has already been applied successfully within the valley fill sediments, whereas surface exposure dating may provide additional means to extend and corroborate these results (SiAme ET AL. 1997; RobINSON ET AL. 2005; SPENCER \& RoBINSON 2008). Against this background, the unravelling of landscape history has shown to produce valuable insights into the Late Quaternary paleoenvironmental evolution of the Quebrada de Purmamarca and should provide an essential base for future research in the Eastern Cordillera.

\section{Acknowledgements}

The authors would like to thank the Universidad Nacional de Salta, Argentina, for logistical and academic support. Fruitful discussions with J. A. SAlfity (Salta), D. Busche (Würzburg) and I. SABino (Salta) as well as the helpful comments of F. Preusser (Bern) and S. Buckman (Wollongong) are gratefully acknowledged. Field work was much facilitated by the personal effort and academic assistance of I. WALz (Würzburg).

\section{Literature}

Abraham de Vazquez, E. M., Garleff, K., Liebricht, H., Regairaz, A. C., Schäbitz, F., Squeo, F. A., Stingl, H., Veit, H. ¿ Villagrán, C. (2000): Geomorphology and Paleoecology of the Arid Diagonal in Southern South America. - Zeitschrift für angewandte Geologie, Sonderheft 1: $55-61$.

Aguero, P. N. (1986): Comentarios acerca de la Erosión Hídrica en la Quebrada de Humahuaca. - Revista Proyección, Centro de Ingenieros y Agrimensores de Jujuy, Año I (No.1): 14-21.

Ahumada, A. L. (2002): Periglacial phenomena in the high mountains of northwestern Argentina. - South African Journal of Science, 98 (March/April): 166-170.

Alcalde, J. A. \& Kulemeyer, J. J. (1999): The Holocene in the South-Eastern region of the Province Jujuy, North-West Argentina. - Quaternary International, 57-58: 113-116.

Alonso, R. L., Bookhagen, B., Carrapa, B., Coutand, I., Haschke, M., Hilley, G. E., Schoenbohm, L., Sobel, E. R., Strecker, M. R., Trauth, M. H. \& Villanueva, A. (2006): Tectonics, Climate, and Landscape Evolution of the Southern Central Andes: the Argentine Puna Plateau and Adjacent Regions between 22 and $30^{\circ}$ S. - Oncken, O., Chong, G., Franz, G., Giese, P., Götze, H.-J., Ramos, V. A., Strecker, M. R. \& Wigger, P. (ed.): The Andes. Active Subduction Orogeny: 265-282; (Springer).

Amengual, R. \& Zanettini, J. C. (1974): Geología de la Quebrada de Humahuaca entre Uquía y Purmamarca (Provincia de Jujuy). - Revista de la Asociación Geológica Argentina, 29 (1): 30-40.

Argollo, J. \& Mourguiart, P. (2000): Late Quaternary climate history of the Bolivian Altiplano. - Quaternary International, 72 (1): 37-51.

Azarevich, M., Novara, M., Armella, M., Deus, R. ¿ Sánchez, M. C. (1999): Geomorfología de la región de Tilcara, Jujuy. - XIV Congreso Geológico Argentino Actas, T II: 31-34.

Baker, P. A., Rigsby, C. A., Seltzer, G. O., Fritz, S. C., Lowenstein T. K., Bacher, N. P. \& Veliz, C. (2001): Tropical climate changes at millennial and orbital timescales on the Bolivian Altiplano. - Nature, 409: 698-701.

Baker, P. A., Seltzer, G. O., Fritz, S. C., Dunbar, R. B., Grove, M. J., Tapia, P. M., Cross, S. L., Rowe, H. D. \& Broda, J. P. (2001): The History of South American Tropical Precipitation for the Past 25,000 Years. - Science, 291 (5504): 640-643.

Becker, H. (1966): Vergleichende Betrachtung der Entstehung von Erdpyramiden in verschiedenen Klimagebieten der Erde. - Kölner Geographische Arbeiten, 17: 17-111.

BiAnchi, A. R. \& YAÑEZ, C. (1992): Las precipitaciones del Noroeste Argentino. - Salta (Instituto Nacional de Tecnología Agropecuaria).

Blair, T. C. \& McPherson, J. (1994): Alluvial Fans and their Natural Dis- tinction from Rivers Based on Morphology, Hydraulic Processes, Sedimentary Processes, and Facies Assemblages. - Journal of Sedimentary Research, A 64 (3): 450-489.

Bookhagen, B., Haselton, K. \& Trauth, M. H. (2001): Hydrological modelling of a Pleistocene landslide-dammed lake in the Santa Maria Basin, NW Argentina. - Palaeogeography, Palaeoclimatology, Palaeoecology, 169 (1-2): 113-127.

Bookhagen, B., Thiede, R. C. \& Strecker, M. R. (2005): Late Quaternary intensified monsoon phases control landscape evolution in the northwest Himalaya. - Geology, 33 (2): 149-152.

Bull, W. B. (1979): Threshold of critical power in streams. - Geological Society of America Bulletin, 90: 453-464.

Bull, W. B. (1988): Floods; Degradation and Aggradation. - Baker, V. R., Kochel, R. C. \& Patton, P. C. (ed.): Flood Geomorphology: 157-165;

Carignano, C. A. (1999): Late Pleistocene to recent climate change in Cordoba Province, Argentina: Geomorphological evidence. - Quaternary International, 57-58: 117-134.

Cencetti, C., Rivelli, F. R. \& Tacconi, P. (2006): Dinamica geomorfologica e problematiche geologico-ambientali nel bacino del Rio Purmamarca (Provincia di Jujuy, Argentina nord-occidentale). - Giornale di Geologia Applicata 4, 4: 206-212.

Chayle, W. \& WAYNe, W. J. (1995): Impact of Erosion, Mass Wasting, and Sedimentation on Human Activities in the Río Grande Basin, Jujuy Province, Argentina. - Environmental \& Engineering Geoscience, 1 (4): 403-416.

Costa, J. E. (1984): Physical Geomorphology of Debris Flows. - Costa, J. E. \& Fleisher, P. J. (ed.): Developments and Applications of Geomorphology: 268-317;

Costa, J. E. \& Schuster, R. L. (1988): The formation and failure of natural dams. - Geological Society of America Bulletin, 100 (7): 1054-1068.

De Ferraris, C. I. C. (1940): Corrimiento de Bloques de Montaña en los alrededores de Purmamarca, Departamento de Tumbaya (Provincia de Jujuy). - Tesis del Museo de la Plata, 1: 98.

ENDLICHER, W. (1995): Zur Witterungsklimatologie von Nordwestargentinien. - Marburger Geogr. Schriften, 128: 17-43.

FAO (2006): Guidelines for Soil Description. - ftp://ftp.fao.org/docrep/ fao/009/a0541e00.pdf

FERnÁndeZ, J. (1984): Variaciones climáticas en la Prepuna Jujeña. Intervalo 5000-2000 años A.P. de interes para la archeología. - IANIGLA Anales, 6: 73-82.

Fernández, J., Markgraf, V., Panarello, H. O., Albero, M., AngioLini, F. E., VAlencio, S. \& Arriaga, M. (1991): Late Pleistocene/Early Holocene Environments and Climates, Fauna, and Huma Occupation in the Argentine Altiplano. - Geoarchaeology, 6 (3): 251-272.

FitzPatrick, E. A. (1993): Soil Microscopy and Micromorphology. (Wiley).

Fochler-HAuke, G. (1952): Verwitterungs-, Erosions- und Aufschüttungsvorgänge in nordwest-argentinischen Gebirgstälern. - Naturwissenschaftliche Rundschau, 5 (2): 65-71.

Fox, A. N. \& STREcKer, M. R. (1991): Pleistocene and Modern Snowlines in the Central Andes (24-28 S). - Bamberger Geographische Schriften, 11: 169-182.

Fritz, S. C., Baker, P. A., Lowenstein, T. K., Seltzer, G. O., Rigsby, C. A., Dwyer, G. S., Tapia, P. M., Arnold, K. K., Ku, T.-L. \& Luo, S. (2004): Hydrologic variation during the last 170,000 years in the southern hemisphere tropics of South America. - Quaternary Research, 61 (1): 95-104.

García Codron, J. C., Ruiz Pino, Y., Silió Cervera, F. ひ Villaverde GonzÁLEZ, C. (1999): Las Formaciones Vegetales en La Quebrada de Humahuaca, Relación con los Factores Físicos y Humanos. http://www.geog.leeds.ac.uk/groups/andes/informes/argveg.htm

GarlefF, K., Schäbitz, F., Stingl, H. \& VeIt, H. (1991): Jungquartäre Landschaftsentwicklung und Klimageschichte beiderseits der Ariden Diagonale Südamerikas. - Bamberger Geographische Schriften, 11: 359-394.

GarlefF, K. \& Stingl, H. (1985): Höhenstufen und ihre Raumzeitlichen Veränderungen in den Argentinischen Anden. - Zbl. Geol. Paläont. Teil I, (11/12): 1701-1707.

Garreaud, R. D. \& Aceituno, P. (2007): Atmospheric Circulation and Climatic Variability. - Veblen, T. T., Young, K. R. \& Orme, A. R. (ed.): The Physcial Geography of South America: 45-59; Oxford (Oxford University Press).

Goudie, A. S. (1983): Calcretes. - Goudie, A. S. \& Pye, K. (ed.): Chemical sediments and geomorphology: precipitates and residua in the nearsurface environment: 93-132; (Academic Press).

Greeley, R., Christensen, P. \& Carrasco, R. (1989): Shuttle radar images 
of wind streaks in the Altiplano, Bolivia. - Geology, 17 (7): 665-668.

Hagedorn, J. (1970): Zum Problem der Glatthänge. - Z. f. Geomorph. N.F., 14: $103-113$.

HARveY, A. M. (1997): The role of alluvial fans in arid zone fluvial systems. - Thomas, D. S. G. (ed.): Arid Zone Geomorphology: Process, Form and Change in Drylands: 233-259;

Haselton, K., Hilley, G. \& Strecker, M. R. (2002): Average Pleistocen Climatic Patterns in the Southern Central Andes: Controls on Mountain Glaciation and Paleoclimate Implications. - The Journal of Geology, 110: 211-226.

Hermanns, R. L., Niedermann, S., Garcia, A. V., Sosa Gomez, J. STRECKER, M. R. (2001): Neotectonics and catastrophic failure of mountain fronts in the southern intra-Andean Puna Plateau, Argentina. - Geology, 29 (7): 619-622.

Hermanns, R. L. \& Schellenberger, A. (2008): Quaternary tephrochronology helps define conditioning factors and triggering mechanisms of rock avalanches in NW Argentina. - Quaternary International, 178 (1): 261-275.

Hermanns, R. L. \& Strecker, M. R. (1999): Structural and lithological controls on large Quaternary rock avalanches (sturzstroms) in arid northwestern Argentina. - Geological Society of America Bulletin, 111 (6): 934-948

Hernández, R., Reynolds, J. \& Disalvo, A. (1996): Analisis tectonosedimentario y ubicación geocronológica del Grupo Oran en el Río Iruya - Boletin Informaciones Petroleras, Buenos Aires, 45: 80-93.

Hilley, G. E. \& Strecker, M. R. (2005): Processes of oscillatory basin filling and excavation in a tectonically active orogen: Quebrada de Toro Basin, NW Argentina. - Geological Society of America Bulletin, 117 (7): 887-901

IgARZÁBAL, A. (1991): Morfología de las Provincias de Salta y Jujuy. - Revista del Instituto de Geología y Mineria, 8: 97-121.

KeIDEL, H. (1913): Junge Fluviatile Aufschüttungen in den Nördlichen Argentinischen Anden. - Geologische Charakterbilder, 18.

Kemp, R. A., King, M., Toms, P., Derbyshire, E., Sayago, J. M. \& Collantes, M. M. (2004): Pedosedimentary development of part of a Late Quaternary loess-palaeosol sequence in northwest Argentina. Journal of Quaternary Science, 19 (6): 567-576.

Kennan, L. (2000): Large-Scale Geomorphology of the Andes: Interrelationships of Tectonics, Magmatism and Climate. - Summerfield, M. A. (ed.): Geomorphology and Global Tectonics: 169-199;

KLeinert, K. \& Strecker, M. R. (2001): Climate change in response to orographic barrier uplift: Paleosol and stable isotope evidence from the late Neogene Santa Maria basin, northwestern Argentina. - Geological Society of America Bulletin, 113 (6): 728-742.

Knighton, D. (1998): Fluvial Forms and Processes. - (Arnold)

KRISL, P. (1999): Beobachtungen zur Frage pedologischer Kalkanreicherungen in NW-Argentinien. - Bamberger Geographische Schriften, 19: $35-47$.

KüHN, F. (1924): Die Tallandschaft von Humahuaca im nordwestlichen Argentinien. - Geographische Zeitschrift, 30 (1): 7-17.

Kulemeyer, J. A., Lupo, L. C., Kulemeyer, J. J. \& Laguna, L. R. (1999): Desarrollo Paleoecológico Durante las Ocupaciones Humanas del Precerámico del Norte de la Puna Argentina. - Bamberger Geographische Schriften, 19: 233-255.

Kulemeyer, J. J. (2005): Holozänentwicklung im Einzugsgebiet des Río Yavi (Jujuy / Argentinien). - Unpublished PhD-Thesis, Fakultät für Biologie, Chemie und Geowissenschaften, University of Bayreuth.

Kull, C., Hanni, F., Grosjean, M. \& Veit, H. (2003): Evidence of a massive LGM cooling in NW-Argentina $\left(22^{\circ} \mathrm{S}\right)$ derived from a glacier climate model. - Quaternary International, 108 (1): 3-11.

Kull, C., Imhof, S., Grosjean, M., Zech, R. \& Veit, H. (2008): Late Pleistocene glaciation in the Central Andes: Temperature versus humidity control - A case study from the eastern Bolivian Andes $\left(17^{\circ} \mathrm{S}\right)$ and regional synthesis. - Global and Planetary Change, 60 (1-2): 148-164.

Lowe, D. R. (1979): Sediment Gravity Flows: their Classification and some Problems of Application to Natural Flows and Deposits. - SEPM Special Publication, 27: 75-82

Lupo, L. C., Bianchi, M., Araoz, E., Grau, R., Lucas, C., Kern, R, Camacho, M., Tanner, W. \& Grosjean, M. (2006): Climate and human impact during the past 2000 years as recorded in the Lagunas de Yala, Jujuy, northwestern Argentina. - Quaternary International 158 (1): 30-43.

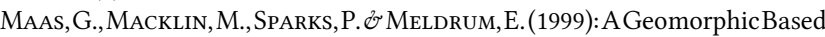
Record of Debris-Flow Events in the Catchment of the Arroyo del Medio, Northwest Argentina. Project Working Paper, Preliminary Report. - http://www.geog.leeds.ac.uk/groups/andes/informes/geomorp.htm
Markgraf, V. (1985): Paleoenvironmental History of the last 10,000 Years in Northwestern Argentina. - Zbl. Geol. Paläont. Teil I, (11/12) 1739-1749.

Marrett, R. \& Strecker, M. R. (2000): Response of intracontinental deformation in the central Andes to late Cenozoic reorganization of South American Plate motions. - Tectonics, 19 (3): 452-467.

May, J.-H. (2002): The Quebrada de Purmamarca, Jujuy, NW Argentina: Landscape Evolution and Morphodynamics in the Semi-Arid Andes. - Diploma Thesis, Institute of Geography, University of Würzburg. http://www.opus-bayern.de/uni-wuerzburg/volltexte/2009/3441/

MAY, J.-H. (2008): A geomorphological map of the Quebrada de Purmamarca, Jujuy, NW Argentina. - Journal of Maps, v2008: 211-224.

Miall, A. D. (1996): The Geology of Fluvial Deposits. Sedimentary Facies, Basin Analysis, and Petroleum Geology. - (Springer).

Milana, J. P. (1994): Propuesta de clasificación de abánicos aluviales en base a los procesos sedimentarios asociados. - V Reunión Argentina de Sedimentología: 289-294.

Mon, R. \& Salfity, J. A. (1995): Tectonic Evolution of the Andes of Northern Argentina. - Tankard, A. J., Suárez, R. S. \& Welsink, H. J. (ed.) Petroleum basins of South America: 269-283;

Nemec, W. \& KazAnci, N. (1999): Quaternary colluvium in west-central Anatolia: sedimentary facies and palaeoclimatic significance. - Sedimentology, 46 (1): 139-170.

Nemec, W. \& SteEL, R. J. (1984): Alluvial and Coastal Conglomerates: Their Significant Features and some Comments on Gravelly Mass-flow Deposits. - Koster, E. H. \& Steel, R. J. (ed.): Sedimentology of Gravels and Conglomerates: 1-31;

Placzek, C., Quade, J. \& Patchett, P. J. (2006): Geochronology and stratigraphy of late Pleistocene lake cycles on the southern Bolivian Altiplano: Implications for causes of tropical climate change. - Geological Society of America Bulletin, 118 (5): 515-532.

Pratt, B., Burbank, D. W., Heimsath, A. \& OJha, T. (2002): Impulsive alluviation during early Holocene strengthened monsoons, centra Nepal Himalaya. - Geology, 30 (10): 911-914

Prieto, M. R., Herrera, R. \& Dussel, P. (2000): Archival Evidence for some Aspects of Historical Climate Variability in Argentina and Bolivia During the 17th and 18th Centuries. - Smolka, P. \& Volkheimer, W. (ed.): Southern Hemisphere Paleo- and Neoclimates (IGCP 341) 127-142;

Prohaska, F. (1976): The Climates of Argentina, Paraguay and Uruguay. - Schwerdtfeger, W. (ed.): Climates of Central and South America: 13-112;

Ramos, V. A., Turic, M. A. \& Zuzek, A. B. (1967): Geología de las Quebradas de Huichaira-Pocoya, Purmamarca y Tumbaya Grande en la Margen Derecha de la Quebrada de Humahuaca (Provincia de Jujuy) - Revista de la Asociación Geológica Argentina, 22 (3): 209-221.

Reynolds, J. H., Galli, C. I., Hernández, R. M., Idleman, B. D., Kotila, J. M., Hilliard, R. V. \& Naeser, C. W. (2000): Middle Miocene Tectonic Development of the Transition Zone, Salta Province, Northwest Argentina: Magnetic Stratigraphy from the Metán Subgroup, Sierra de González. - Geological Society of America Bulletin, 112 (11): 17361751.

Reynolds, J. H., Hernandez, R. M., Galli, C. I. \& Idleman, B. D. (2001): Magnetostratigraphy of the Quebrada La Porcelana section, Sierra de Ramos, Salta Province, Argentina: age limits for the Neogene Oran Group and uplift of the southern Sierras Subandinas. - Journal of South American Earth Sciences, 14 (7): 681-692.

Robinson, R. A. J., Phillips, W. M., Spencer, J. Q., Kubik, P. W., Strecker, M. R. \& Alonso, R. L. (2005): Correlation of Basin-Scale Denudation Rates and Precipitation Increased over the last 200 ka in NW Argentina. - European Geosciences Union, Abstracts of the Contributions of the EGU General Assembly 2005: EGU05-A-09393.

Robinson, R. A. J., Spencer, J. Q., Phillips, W. M., Kubik, P. W., Strecker, M. R. \& Alonso, R. N. (2004): Basin-Scale Denudation Rates and Exposure Ages using 10Be and Optically Stimulated Luminescence Dating in NW Argentina. - ETH/PSI Ion Beam Physics Annual Report 2004.

Robinson, R. A. J., Spencer, J. Q. G., Strecker, M. R., Richter, A. \& Alonso, R. N. (2005): Luminiscence dating of alluvial fans in intramontane basins of NW Argentina. - Harvey, A. M., Mather, A. E. \& Stokes, M. (ed.): Alluvial Fans: Geomorphology, Sedimentology, Dynamics: 153-168; London (Geological Society of London).

Ruthsatz, B. (1977): Pflanzengesellschaften und ihre Lebensbedingungen in den Andinen Halbwüsten Nordwest-Argentiniens. - Dissertationes Botanicae, 39

Salfity, J. A., Brandán, E. M., Monaldi, C. N. \& Gallardo, E. F. (1984): Tectónica Compresiva Cuaternaria en la Cordillera Oriental Argentina 
Latitud de Tilcara (Jujuy). - IX Congreso Geológico Argentino Actas, T II: 427-434.

Salfity, J. A., Gorustovich, S. A., González, R. E., Monaldi, C. R., Marquillas, R. A., Galli, C. I. \& Alonso, R. N. (1996): Las cuencas Terciarias Posincaicas de los Andes Centrales de la Argentina. - XIII Congreso Geológico Argentino y III Congreso de Exploración de Hidrocarburos, Actas I: 453-471.

Sancho, C., PeñA, J. L., Rivelli, F., Rhodes, E. ¿ Muñoz, A. (2008): Geomorphological evolution of the Tilcara alluvial fan (Jujuy Province, NW Argentina): Tectonic implications and palaeoenvironmental considerations. - Journal of South American Earth Sciences, 26 (1): 68-77.

SснӓвIтZ, F. (1999): Vegetation and Climate History on the Eastern Flank of the Sierra de Santa Victoria, Jujuy Province, NW-Argentina (first results). - Zbl. Geol. Paläont. Teil I, (Heft 7/8): 969-984.

SCHEFFER, F. \& SCHACHTSCHABEL, P. (2002): Lehrbuch der Bodenkunde. (Spektrum).

SCHELlenberger, A. (2006): Die Lösse im Becken von Tafí (Nordwestargentinien) - ein Langzeitklimaarchiv für das südamerikanische Monsunsystem? - Geographica Helvetica, 61 (2): 107-119.

Schellenberger, A., Heller, F. ¿ Veit, H. (2003): Magnetostratigraphy and magnetic susceptibility of the Las Carreras loess-paleosol sequence in Valle de Tafi, Tucumán, NW-Argentina. - Quaternary International, 106-107: 159-167.

Schellenberger, A. ¿ Veit, H. (2006): Pedostratigraphy and pedological and geochemical characterization of Las Carreras loess-paleosol sequence, Valle de Tafi, NW-Argentina. - Quaternary Science Reviews, 25 (7-8): 811-831.

Schumm, S. A. (2005): River Variability and Complexity. - Cambridge (Cambridge University Press).

SEGEMAR-ITGE (1998): Estudio Geológico Integrado de la Quebrada de Humahuaca. Geología Regional y Geomorfología. Anales XXX. Subsecretaria de Minería de la Nacion.

Siame, L. L., Bourlès, D. L., Sébrier, M., Bellier, O., Castano, J. C., ArauJo, M., Perez, M., Raisbeck, G. M. ש Yiou, F. (1997): Cosmogenic dating ranging from 20 to $700 \mathrm{ka}$ of a series of alluvial fan surfaces affected by the El Tigre fault, Argentina. - Geology, 25 (11): 975-978.

Soler, R. D. (2002): Geología Ambiental de la Cuenca del Río Purmamarca (Jujuy -Argentina). - Unpublished PhD-Thesis, Universidad Nacional de Salta.

SPENCER, J. Q. G. \& Robinson, R. A. J. (2008): Dating intramontane alluvial deposits from NW Argentina using luminescence techniques: Problems and potential. - Geomorphology, 93 (1-2): 144-155.

StingL, H. \& GARLEFF, K. (1983): Beobachtungen zur Hang- und Wandentwicklung in der Periglazialstufe der subtropisch-semiariden Hochanden Argentiniens. - Poser, H. \& SCHUNKE, E. (ed.): Mesoformen des Reliefs im heutigen Periglazialraum: Bericht über ein Symposium: 199-213;

Strecker, M. R., Alonso, R. N., Bookhagen, B., Carrapa, B., Hilley, G. E., Sobel, E. R. \& Trauth, M. H. (2007): Tectonics and Climate of the Southern Central Andes. - Annual Review of Earth and Planetary Sciences, 35 (1): 747-787.
Strecker, M. R., Cerveny, P., Bloom, A. L. \& Malizia, D. (1989): Late Cenozoic Tectonism and Landscape Development in the Foreland of the Andes: Northern Sierras Pampeanas $\left(26^{\circ}-28^{\circ} \mathrm{S}\right)$, Argentina. - Tectonics, 8 (3): 517-534.

Strecker, M. R. \& MARrett, R. (1999): Kinematic evolution of fault ramps and its role in development of landslides and lakes in the northwestern Argentine Andes. - Geology, 27 (4): 307-310.

Tchilinguirian, P. \& Pereyra, F. X. (2001): Geomorfología del Sector Salinas Grandes - Quebrada de Humahuaca, Provincia de Jujuy. - Revista de la Asociación Geológica Argentina, 56 (1): 3-15.

Trauth, M. H., Alonso, R. A., Haselton, K. R., Hermanns, R. L. \& StreckER, M. R. (2000): Climate change and mass movements in the NW Argentine Andes. - Earth and Planetary Science Letters, 179 (2): 243-256.

Trauth, M. H., Bookhagen, B., Marwan, N. \& Strecker, M. R. (2003): Multiple landslide clusters record Quaternary climate changes in the northwestern Argentine Andes. - Palaeogeography, Palaeoclimatology, Palaeoecology, 194 (1-3): 109-121.

Trauth, M. H. \& Strecker, M. R. (1999): Formation of landslide-dammed lakes during a wet period between 40,000 and 25,000 yr B.P. in northwestern Argentina. - Palaeogeography, Palaeoclimatology, Palaeoecology, 153 (1-4): 277-287.

Turner, J. C. M. (1970): The Andes of Northwestern Argentina. - Geologische Rundschau, 59 (3): 1028-1063.

VIERs, G. (1967): La Quebrada de Humahuaca (province de Jujuy, Argentine) et les problèmes morphologiques des Andes sèches. - Annales de Geographie, 76: 411-433.

Weissmann, G. S., Mount, J. F. \& FogG, G. E. (2002): Glacially driven cycles in accumulation space and sequence stratigraphy of a stream-dominated alluvial fan, San Joaquin Valley, U.S.A. - Journal of Sedimentary Research, 72 (2): 140-152.

WERnER, D. J. (1971): Böden mit Kalkanreicherungs-Horizonten in NWArgentinien. - Göttinger Bodenkundliche Berichte, 19: 167-181.

Werner, D. J. (1984): Zur Genese der jüngeren Flächenniveaus im Gebiet von Huacalera (Quebrada de Humahuaca, NW-Argentinien). - Zbl. Geol. Paläont. Teil I, (Heft 11/12): 1527-1539.

Wilson, M. A. \& Nettleton, W. D. (2009): Unraveling Genetic Processes in Arid Soils Using Micromorphology. - USDA-NRCS. wvlc.uwaterloo. ca/biology447/modules/module8/soil/genetic.pdf.

Wright, V. P. \& Tucker, M. (1991): Calcretes. - The International Association of SEDimentologists, Series: 352 pages; Carlton (Blackwell).

Yacobaccio, H. D. ひ Morales, M. (2005): Mid-Holocene environment and human occupation of the Puna (Susques, Argentina). - Quaternary International, 132 (1): 5-14.

Zipprich, M., Reizner, B., Zech, W., Stingl, H. \& Veit, H. (2000): Upper Quaternary Landscape and Climate Evolution in the Sierra de Santa Victoria (North-Western Argentina) Deduced from Geomorphologic and Pedogenic Evidence. - Zbl. Geol. Paläont. Teil 1, (Heft 7/8): 997-1011. 